\title{
Pola makan, asupan zat gizi, dan status gizi anak balita Suku Anak Dalam di Nyogan Kabupaten Muaro Jambi Provinsi Jambi
}

\author{
Erni $^{1}$, M. Juffrie ${ }^{2}$, M. Primiaji Rialihanto ${ }^{3}$
}

\begin{abstract}
Background: Anak Dalam Tribal Community lives in an isolated area with meagre living pattern and numerous limitations. This condition affects eating pattern and nutritional status of underfives of Anak Dalam Tribe.

Objective: To identify eating pattern, nutrient intake, and nutritional status of underfives of Anak Dalam Tribe at Nyogan, District of Muaro Jambi, Province of Jambi.

Method: The study was observational with cross sectional design. Population of the study were underfives of Anak Dalam Tribe aged 24-59 months at Nyogan, District of Muaro Jambi, Province of Jambi. Data obtained consisted of eating pattern, nutrient intake and nutritional status, characteristics of parents and subject as well as general overview of the location of the study. Chi-square test was used to find out the relationship between nutrient intake and nutritional status. Results: As much as $54.2 \%$ of children of Anak Dalam Tribe had varied types of foods and $52.1 \%$ of them had good eating frequency; $45.8 \%$ had incomplete types of foods and $47.9 \%$ had poor eating frequency. Average energy and protein intake of underfives of Anak Dalam Tribe were 1,020.93 $\pm 298.68 \mathrm{kcal} /$ day and $28.49 \pm 8.08 \mathrm{~g} / \mathrm{day}$. Most of the children had adequate energy and protein intake ( $\geq 80 \%$ nutrition sufficiency); i.e. $60.4 \%$ and $77.1 \%$ subsequently. Those who had inadequate energy and protein intake were $39.6 \%$ and $22.9 \%$ subsequently. Inadequate nutritional status of underfives of Anak Dalam Tribe using indicator of weight/age was $16.7 \%$, height/age was $12.5 \%$, and weight/height was $8.3 \%$.

Conclusion: There was significant relationship between nutrient intake (energy and protein) and nutritional status of underfives of Anak Dalam Tribe.
\end{abstract}

KEY WORDS eating pattern, nutrient intake, nutritional status

\section{PENDAHULUAN}

Tantangan utama dalam pembangunan suatu bangsa adalah membangun sumber daya manusia (SDM) berkualitas yang sehat, cerdas, dan produktif. Pencapaian pembangunan manusia yang diukur dengan indeks pembangunan manusia belum menunjukkan hasil yang menggembirakan dalam tiga dasawarsa terakhir. Pada tahun 2003, IPM (indeks pembangunan manusia) Indonesia masih rendah yaitu berada pada peringkat 112 dari 174 negara, lebih rendah dibandingkan dengan negara-negara tetangga. Rendahnya IPM ini sangat dipengaruhi oleh rendahnya status gizi dan status kesehatan penduduk (1).

Keadaan gizi masyarakat menggambarkan tingkat kesehatan yang diukur dengan keseimbangan antara kebutuhan dan asupan zat-zat gizi yang dikonsumsi masyarakat tersebut. Keseimbangan antara kebutuhan dan asupan zat-zat gizi dapat terjaga dengan baik apabila seseorang menerapkan pola konsumsi makan yang seimbang (2).

Untuk memantau keadaan gizi masyarakat, kelompok anak balita merupakan parameter yang sangat sesuai karena dinilai berada pada masa yang cukup sensitif. Hal ini berhubungan erat dengan konsumsi energi dan protein yang merupakan dua jenis zat gizi yang paling sering menimbulkan masalah gizi kesehatan pada skala nasional atau daerah luas regional di Indonesia (3). Masa balita merupakan masa kritis dalam upaya menciptakan SDM yang berkualitas. Gagal tumbuh yang terjadi akibat kurang gizi pada masa-masa emas ini akan berakibat buruk pada kehidupan balita di masa yang akan datang dan sulit diperbaiki (4).

Hasil pemantauan status gizi di Provinsi Jambi tahun 2006, diketahui prevalensi gizi buruk pada anak balita sebesar $1,9 \%$ dan gizi kurang sebesar $9,9 \%$. Prevalensi gizi buruk dan gizi kurang di Kabupaten Muaro Jambi jauh lebih tinggi dibanding di Provinsi Jambi, yaitu masing-masing sebesar $4,9 \%$ dan $17,9 \%$. Namun demikian, prevalensi status gizi pada Suku Anak Dalam (SAD) berdasarkan referensi yang ada sampai saat ini belum pernah dilakukan survei (5).

SAD merupakan salah satu komunitas adat terpencil yang ada di Provinsi Jambi. Mereka hidup berkelompok dalam kegiatan sosial budaya yang bersifat lokal spesifik dan belum terlibat dalam jaringan pelayanan baik ekonomi, sosial, maupun politik. Salah satu wilayah yang didiami oleh SAD adalah Desa Nyogan Kecamatan Mestong Kabupaten Muaro Jambi. Lokasinya berjarak sekitar $68 \mathrm{~km}$ dari Kota Jambi. SAD yang ada di lokasi ini terdiri dari 66 kepala keluarga

\footnotetext{
Dinas Kesehatan Provinsi Jambi, Jl. R.M. Noer Atmadibrata No. 2 Telanaipura Jambi

2 Bagian Anak RS Dr. Sardjito, JI. Kesehatan, Yogyakarta, e-mail: juffrie@indosat.net.id

3 Politeknik Kesehatan Departemen Kesehatan RI Yogyakarta, Jl. Tatabumi No. 3 Yogyakarta
} 
(KK) yang terbagi menjadi 2 rukun tetangga (RT) dan masingmasing RT terdiri dari 33 KK. Sejak tahun 2004, mereka mulai tinggal menetap. Pada umumnya, pola hidup mereka masih sangat sederhana dan hidup di daerah terpencil dengan berbagai keterbatasan, seperti ketiadaan tempat tinggal yang layak, kekurangan pangan, krisis air bersih, sanitasi dan kesehatan yang buruk. Frekuensi makan sebagian masyarakat SAD hanya dua kali sehari. Keadaan ini secara tidak langsung disebabkan ibu sebagai penyedia makanan tidak dapat pulang pada tengah hari untuk mempersiapkan makanan. Akibatnya keluarga hanya makan pada pagi hari sebelum ibu berangkat untuk mencari makanan di ladang atau di dalam hutan dan sore hari setelah ibu kembali. Terbatasnya variasi makanan dan jumlah frekuensi makan yang hanya dua kali sehari tentu akan mempengaruhi kecukupan gizi masyarakat SAD, terlebih bagi anak balita yang membutuhkan asupan tambahan untuk pertumbuhan dan perkembangan. Perilaku sehat pada SAD juga sangat rendah. Faktor-faktor ini akan menjadi mata rantai penyebab terjadinya kurang gizi pada anak balita SAD (6).

Penelitian ini bertujuan untuk mengetahui pola makan, asupan zat gizi, dan status gizi anak balita SAD di Nyogan Kabupaten Muaro Jambi Provinsi Jambi.

\section{BAHAN DAN METODE}

Jenis penelitian ini adalah observasional dengan rancangan cross sectional, yaitu peneliti mempelajari hubungan variabel bebas dengan variabel terikat dan pengukuran kedua variabel tersebut dilakukan pada saat yang sama. Populasi penelitian ini adalah 50 anak balita SAD (kategori menetap) yang berumur 24-59 bulan di Nyogan Kabupaten Muaro Jambi Provinsi Jambi. Subjek penelitian ini adalah semua anak balita SAD yang berumur 24-59 bulan yang memenuhi kriteria inklusi maupun eksklusi, sedangkan responden penelitian adalah ibu dari subjek penelitian. Kriteria inklusi meliputi balita berumur 24-59 bulan dan orang tuanya bersedia menjadi responden, sedangkan kriteria eksklusi meliputi subjek yang orang tuanya pindah alamat yang sulit dilacak dan subjek jatuh sakit pada saat penelitian dilaksanakan.

Data karakteristik dan pola makan dikumpulkan dengan wawancara menggunakan kuesioner, data asupan zat gizi dengan metode recall $1 \times 24$ jam selama 3 hari, dan data status gizi didapatkan dengan melakukan pengukuran berat badan (BB) dan tinggi badan (TB). Penelitian dilakukan di Nyogan Kabupaten Muaro Jambi Provinsi Jambi selama 3 bulan (Oktober sampai dengan Desember 2007).

Pengolahan data diawali dengan editing untuk mengecek kelengkapan data, coding untuk memudahkan proses entri data, cleaning atau pembersihan data, dan tahap selanjutnya adalah processing atau entri data. Pengolahan data dilakukan dengan menggunakan program komputer. Penyajian data dilakukan secara tekstular dan tabulasi. Pada tahap awal, dilakukan analisis univariat untuk mengetahui distribusi masing-masing variabel yang meliputi: nilai rata-rata, median, standar deviasi, nilai maksimum dan minimum. Analisis bivariat untuk mengetahui hubungan asupan zat gizi dengan status gizi dengan menggunaakan uji chi square dengan tingkat kemaknaan $95 \%$.

\section{HASIL DAN BAHASAN}

\section{Karakteristik subjek penelitian}

Karakteristik subjek penelitian meliputi jenis kelamin dan umur, sedangkan karakteristik keluarga subjek penelitian yang diteliti meliputi: umur ayah, pendidikan ayah, pekerjaan ayah, umur ibu, pendidikan ibu, pekerjaan ibu, jumlah anggota keluarga, dan jumlah anak balita (Tabel 1).

Dari tabel tersebut diketahui bahwa sebagian besar subjek berjenis kelamin perempuan yaitu sebanyak 25 anak $(52,1 \%)$ dan pada umumnya subjek secara keseluruhan berumur $37-59$ bulan yaitu sebanyak 40 anak $(83,3 \%)$.

Ayah subjek berumur $\leq 30$ tahun sebanyak 29 orang $(60,4 \%)$ dengan tingkat pendidikan sebagian besar tidak sekolah sebanyak 46 orang $(95,8 \%)$ dan pekerjaan sebagai petani sebanyak 28 orang $(58,3 \%)$. Umur ibu subjek sebagian besar $\leq 25$ tahun yaitu sebanyak 27 orang $(56,2 \%)$ dengan tingkat pendidikan sebagian besar tidak sekolah sebanyak 47 orang $(97,9 \%)$ dan memiliki pekerjaan sebagai ibu rumah tangga (IRT) sebanyak 42 orang ( 87,5\%). Sebagian besar $(70,8 \%)$ jumlah anggota keluarga subjek $\leq 4$ orang dan yang memiliki 1 anak balita di dalam keluarga sebanyak 36 keluarga (75\%) dan 12 keluarga (25\%) lainnya mempunyai $>1$ anak balita.

\section{Pola makan subjek penelitian}

Pola makan subjek yang meliputi jenis makanan dan frekuensi makan disajikan pada Tabel 2. Berdasarkan tabel tersebut diketahui bahwa sebanyak $54,2 \%$ subjek mengkonsumsi jenis makanan kategori lengkap. Subjek yang termasuk kategori lengkap pada penelitian ini adalah mengkonsumsi 3 kelompok jenis makanan tiap hari, yaitu: makanan pokok (sumber karbohidrat), lauk-pauk (sumber protein), sayur-sayuran dan buah (sumber vitamin dan mineral), sedangkan yang termasuk kategori tidak lengkap apabila tidak mengkonsumsi salah satu dari ketiga jenis kelompok makanan tersebut.

Pada masa silam, jenis makanan pokok subjek yang dikonsumsi antara lain: keladi, ubi kayu, dan ubi jalar; laukpauk biasanya berasal dari binatang buruan seperti babi hutan, rusa, kelinci, dan lain-lain; sedangkan sayur-sayuran dan buah-buahan berasal dari sekitar tempat tinggal mereka seperti daun ubi jalar, daun singkong, dan lain-lain.

Namun saat ini subjek mengkonsumsi nasi sebagai makanan pokok sehari-hari dan tidak lagi menggantungkan lauk-pauk serta sayur dan buah dari hasil buruan di hutan. Sumber protein yang sering dikonsumsi tersebut umumnya berupa ikan sungai (ikan lais, ikan putih, ikan gabus, dan lainlain) yang berasal dari penangkapan ikan lokal. Sumber makanan juga diperoleh dari luar atau dari masyarakat yang 
TABEL 1. Karakteristik subjek penelitian beserta keluarganya

\begin{tabular}{|c|c|c|}
\hline Karakteristik keluarga & $\mathbf{n}$ & $\%$ \\
\hline \multicolumn{3}{|l|}{ Jenis kelamin } \\
\hline Laki-laki & 23 & 47,9 \\
\hline Perempuan & 25 & 52,1 \\
\hline \multicolumn{3}{|l|}{ Umur } \\
\hline 24-36 bulan & 8 & 16,7 \\
\hline $37-59$ bulan & 40 & 83,3 \\
\hline \multicolumn{3}{|l|}{ Umur ayah } \\
\hline$\leq 30$ tahun & 29 & 60,4 \\
\hline$>30$ tahun & 19 & 39,6 \\
\hline \multicolumn{3}{|l|}{ Pendidikan ayah } \\
\hline Tidak sekolah & 46 & 95,8 \\
\hline Sekolah dasar (SD) & 2 & 4,2 \\
\hline \multicolumn{3}{|l|}{ Pekerjaan ayah } \\
\hline Nelayan & 20 & 41,7 \\
\hline Petani & 28 & 58,3 \\
\hline \multicolumn{3}{|l|}{ Umur lbu } \\
\hline$\leq 25$ tahun & 27 & 56,2 \\
\hline$>25$ tahun & 21 & 43,8 \\
\hline \multicolumn{3}{|l|}{ Pendidikan ibu } \\
\hline Tidak sekolah & 47 & 97,9 \\
\hline Sekolah dasar (SD) & 1 & 2,1 \\
\hline \multicolumn{3}{|l|}{ Pekerjaan ibu } \\
\hline Ibu rumah tangga & 42 & 87,5 \\
\hline Petani & 6 & 12,5 \\
\hline \multicolumn{3}{|l|}{ Jumlah anggota keluarga } \\
\hline$\leq 4$ orang & 34 & 70,8 \\
\hline$>4$ orang & 14 & 29,2 \\
\hline \multicolumn{3}{|l|}{ Jumlah anak balita } \\
\hline 1 anak balita & 36 & 75 \\
\hline$>1$ anak balita & 12 & 25 \\
\hline
\end{tabular}

datang berjualan ke desa. Selain itu, masyarakat SAD juga kerap mendapat bantuan bahan makanan dari Dinas Kesejahteraan Sosial dan Pemberdayaan Masyarakat (Dinas KSPM) Provinsi Jambi, namun bantuan tersebut hanya bersifat musiman saja. Makanan-makanan tersebut meningkatkan variasi makanan dan saat ini hampir tidak ada lagi bedanya dengan variasi makanan masyarakat luar. Hal ini tentu akan berpengaruh baik terhadap status gizi anak balita SAD.

Frekuensi makan anak balita SAD tidak berbeda jauh dengan masyarakat lainnya. Sebagian besar $(52,1 \%)$ masyarakat sudah memiliki frekuensi makan baik, yaitu $\geq 3$ kali sehari dan sebagian lainnya $(47,9 \%)$ memiliki frekuensi makan tidak baik yaitu < 3 kali sehari (Tabel 2). Menurut Suhardjo dan Kusharto (7), frekuensi makan terutama anak balita memerlukan sekurang-kurangnya tiga kali sehari guna memenuhi kebutuhan gizinya.

\section{Asupan zat gizi subjek penelitian}

Data asupan zat gizi subjek yang meliputi asupan energi dan protein berdasarkan hasil recall dihitung dan dibandingkan dengan angka kecukupan gizi (AKG). Dirjosoenyoto (8) mengklasifikasikan asupan zat gizi menjadi 3 kategori, yaitu lebih, cukup, dan kurang. Asupan zat gizi dan rata-rata asupan zat gizi subjek penelitian disajikan pada Tabel 3. Dari tabel tersebut diketahui bahwa sebagian besar subjek memiliki asupan energi dan asupan protein cukup, masing-masing sebanyak $23(47,9 \%)$ dan $27(56,3 \%)$ anak balita. Rata-rata asupan energi yang didapatkan pada penelitian ini sebesar $1.020,93 \pm 298,68 \mathrm{kkal} / \mathrm{hari}$ dan rata-rata asupan protein sebesar 28,49 $\pm 8,08$ gram/hari.

Untuk memudahkan analisis selanjutnya, data asupan zat gizi kemudian dikategorikan menjadi 2 , yaitu cukup ( $\geq 80 \% A K G$ )

TABEL 2. Pola makan subjek penelitian

\begin{tabular}{lll}
\hline \multicolumn{1}{c}{ Pola makan } & $\mathbf{n}$ & $\mathbf{\%}$ \\
\hline Jenis makanan & & \\
$\quad$ Lengkap & 26 & 54,2 \\
$\quad$ Tidak lengkap & 22 & 45,8 \\
Frekuensi makan & & \\
Baik & 25 & 52,1 \\
Tidak baik & 23 & 47,9 \\
\hline
\end{tabular}


TABEL 3. Asupan zat gizi dan nilai rata-rata asupan zat gizi subjek penelitian

\begin{tabular}{|c|c|c|c|}
\hline Asupan zat gizi & $\mathbf{n}$ & $\%$ & Rata-rata asupan zat gizi $\pm S D$ \\
\hline \multicolumn{4}{|l|}{ Asupan energi } \\
\hline Lebih (> 110\% AKG) & 6 & 12,5 & $1.020,93 \pm 298,68$ \\
\hline Cukup $(80-110 \%$ AKG) & 23 & 47,9 & \\
\hline Kurang $(<80 \%$ AKG $)$ & 19 & 39,6 & \\
\hline \multicolumn{4}{|l|}{ Asupan protein } \\
\hline Lebih (> 110\% AKG) & 10 & 20,8 & $28,49 \pm 8,08$ \\
\hline Cukup (80-110\% AKG) & 27 & 56,3 & \\
\hline Kurang $(<80 \%$ AKG) & 11 & 22,9 & \\
\hline
\end{tabular}

dan kurang (<80\%AKG) (Tabel 4). Asupan energi subjek berada dalam kategori cukup ( $\geq 80 \%$ AKG) sebesar $60,4 \%$, begitu pula asupan proteinnya yang juga berada dalam kategori cukup $(\geq$ $80 \%$ AKG) sebesar 77,1\%. Tingkat kecukupan energi dan protein yang sudah baik ini disebabkan sebagian besar subjek mengkonsumsi menu sehari-hari secara lengkap yang terdiri dari makanan pokok, lauk, sayur-sayuran dan buah-buahan. Di samping itu, sebagian besar subjek juga sudah mempunyai frekuensi makan $\geq 3$ kali sehari dengan jumlah dan kandungan energi yang cukup sesuai dengan kecukupan gizi yang dianjurkan.

Jumlah anak balita dengan asupan energi dan protein yang cukup pada penelitian ini lebih besar dibandingkan dengan penelitian sebelumnya di desa tertinggal di Bengkulu Selatan yang mendapatkan hasil sebanyak $12,90 \%$ anak balita umur 2-5 tahun memiliki asupan energi cukup dan $51,59 \%$ anak balita yang memiliki asupan protein cukup. Perbedaan ini disebabkan oleh beberapa faktor, di antaranya: tingkat ekonomi, pendidikan, dan pengetahuan orang tua (9).

Kondisi wilayah SAD yang dikelilingi oleh sungai dan cukup banyaknya ayah subjek yang bekerja sebagai nelayan juga berpengaruh terhadap kemudahan mendapatkan makanan sumber protein pada anak balita SAD. Sumber protein terbanyak yang dikonsumsi subjek yaitu ikan sungai, seperti: ikan lais, ikan putih, ikan patin, dan ikan gabus yang merupakan kegemaran subjek. Selain itu, mereka sudah mulai dapat membeli bahan makanan di dusun-dusun atau masyarakat yang datang ke lokasi mereka dengan membawa dagangan, sehingga variasi bahan makanan (sumber protein) yang dapat dikonsumsi pun makin banyak, seperti: telur, sardencis, ikan teri, dan ayam. Hal ini didukung oleh tidak ditemukannya jenis makanan tertentu yang dipantang atau dilarang oleh masyarakat SAD, kecuali makanan yang tidak halal menurut agama Islam, sehingga berdampak baik pada status gizi anak balita SAD.

\section{Status gizi subjek penelitian}

Gambaran status gizi subjek, nilai rata-rata, nilai minimum dan maksimum berdasarkan hasil pengukuran antropometri dengan menggunakan indeks berat badan per umur (BB/U), tinggi badan per umur ( $\mathrm{TB} / \mathrm{U})$ dan berat badan per tinggi badan (BB/TB) disajikan pada Tabel 5. Untuk memudahkan analisis selanjutnya, kategori status gizi kemudian dibagi menjadi dua, yaitu cukup ( $\geq 80 \%$ AKG) dan kurang (<80\% AKG) (Gambar 1).

Rata-rata skor-Z berdasarkan indeks BB/U sebesar 0,8415 yang menunjukkan subjek termasuk kategori baik menurut standar WHO/NCHS (nilai skor-Z $\geq-2,00$ )(Tabel 5). Pada Gambar 1 terlihat bahwa subjek sebagian besar berstatus gizi baik yaitu sebesar $83,3 \%$, sedangkan yang berstatus gizi kurang yaitu $16,7 \%$. Kondisi status gizi berdasarkan BB/U ini memberikan gambaran masa tumbuh anak yang bersifat reversibel, karena sangat sensitif terhadap perubahan-perubahan mendadak, seperti: sakit/infeksi, menurunnya nafsu makan atau jumlah makanan yang dikonsumsi, sebaliknya ketika pemenuhan gizi tercapai maka status gizi menjadi lebih baik. Indeks BB/U lebih menggambarkan status gizi seseorang saat ini (current nutritional status) $(10,11,12)$.

Penilaian status gizi berdasarkan indeks TB/U pada Tabel 5 menunjukkan subjek termasuk dalam kategori gizi normal dengan rata-rata skor-Z sebesar -0,329. Hal ini sesuai dengan standar WHO/NCHS dengan kriteria yang dikategorikan dalam status gizi normal bila nilai skor-Z $\geq-2,00$. Pada Gambar 1 terlihat bahwa sebagian besar subjek berstatus gizi normal yaitu sebanyak $87,5 \%$, sedangkan $12,5 \%$ sisanya berstatus

TABEL 4. Asupan zat gizi subjek penelitian

\begin{tabular}{ccc}
\hline Asupan zat gizi & $\mathbf{n}$ & $\%$ \\
\hline Asupan energi & & \\
Cukup & 29 & 60,4 \\
Kurang & 19 & 39,6 \\
Asupan protein & & \\
Cukup & 37 & 77,1 \\
Kurang & 11 & 22,9 \\
\hline
\end{tabular}


gizi pendek. Indeks TB/U dapat memberikan gambaran status gizi masa lalu, karena sifat pertumbuhan yang ireversibel $(10,12)$.

Pada Tabel 5 terlihat bahwa hasil pengukuran status gizi berdasarkan indeks BB/TB termasuk kategori gizi normal dengan rata-rata skor-Z sebesar 0,421 (standar normal WHO/NCHS bila $\geq-2,00$ ) dan pada Gambar 1 terlihat bahwa sebagian besar subjek memiliki status gizi normal yaitu sebanyak $91,7 \%$ dan $8,3 \%$ berstatus gizi kurus. Indeks $\mathrm{BB} / \mathrm{TB}$ merupakan indikator yang baik untuk menyatakan status gizi saat ini, terlebih bila data umur yang akurat sulit diperoleh. Oleh karena itu, BB/TB disebut juga indikator yang independen terhadap umur $(10,12)$.

Dari hasil penelitian ini dapat dikatakan bahwa keadaan status gizi subjek umur 24-59 bulan di Nyogan Kabupaten Muaro Jambi relatif baik karena rata-rata skor-Z ketiga jenis pengukuran $\geq-2,00$. Status gizi yang baik ini disebabkan sebagian besar asupan energi dan protein subjek berada dalam kategori yang cukup. Status gizi yang baik dapat dicapai dengan cara mengkonsumsi makanan yang seimbang, baik kualitas maupun kuantitasnya (13). Persentase anak balita gizi kurang pada penelitian ini lebih rendah dibandingkan penelitian Sudita (14) pada anak balita Suku Baduy di Kecamatan Leuwidamar Kabupaten Lebak Banten yang menemukan sebanyak $23,2 \%$ di antara anak balita tersebut menderita gizi kurang dan sebanyak $13,2 \%$ lainnya menderita gizi buruk. Perbedaan ini kemungkinan disebabkan pola konsumsi anak balita pada penelitian ini lebih baik dibandingkan dengan anak balita Suku Baduy yang dapat dikatakan sangat sederhana (asupan gizi kurang) yaitu lebih banyak yang berasal dari nasi, ikan asin, dan kadang-kadang dengan sayur.

TABEL 5. Status gizi, rata-rata, nilai minimum dan maksimum berdasarkan indeks $B B / U$, $T B / U$ dan $B B / T B$ pada subjek penelitian

\begin{tabular}{lccccc}
\hline \multicolumn{1}{c}{ Status gizi } & $\mathbf{n}$ & $\%$ & Rata-rata \pm SD & Minimum & Maksimum \\
\hline BB/U & 0 & 0 & $-0,8415 \pm$ & $-3,55$ & 1,03 \\
Lebih (> + 2 SD) & 40 & 83,3 & 1,02504 & & \\
Baik (-2 SD s.d. +2 SD) & 7 & 14,6 & & & \\
Kurang (<-2 SD s.d. $\geq-3$ SD) & 1 & 2,1 & & & \\
$\quad$ Buruk (<-3 SD) & & & & \\
TB/U & 42 & 87,5 & $-0,3288 \pm$ & $-5,48$ & \\
$\quad$ Normal (-2 SD s.d. +2 SD) & 6 & 12,5 & 1,62504 & & \\
$\quad$ Pendek (<-2 SD) & 7 & 14,6 & $0,4215 \pm$ & $-2,74$ & \\
BB/TB & 37 & 77,1 & 1,41893 & & \\
$\quad$ Gemuk (> +2 SD) & 4 & 8,3 & & & \\
$\quad$ Normal (-2 SD s.d. +2 SD) & 0 & 0 & & & \\
$\quad$ Kurus (<-2 SD s.d. $\geq-3$ SD) & & &
\end{tabular}

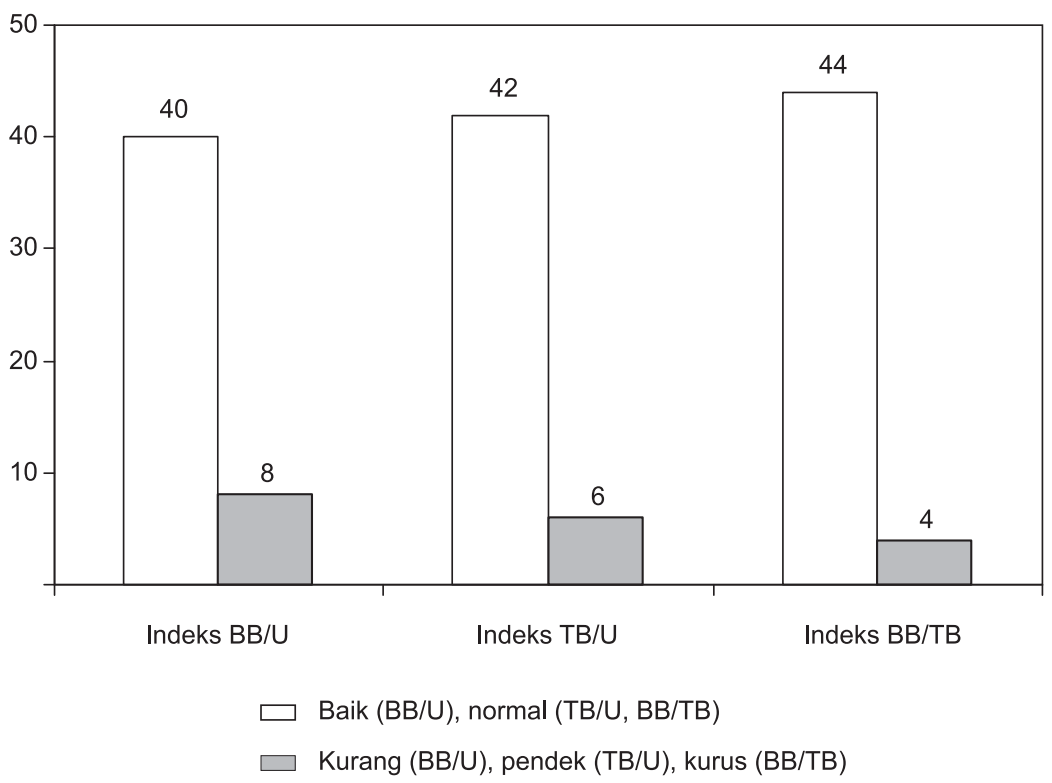

GAMBAR 1. Status gizi subjek penelitian 
TABEL 6. Hubungan asupan energi dan protein dengan status gizi subjek penelitian berdasarkan indeks $B B / U, T B / U, B B / T B$

\begin{tabular}{|c|c|c|c|c|c|c|}
\hline \multirow{3}{*}{ Asupan zat gizi } & \multicolumn{4}{|c|}{ Status Gizi (BB/U) } & \multirow{3}{*}{$\chi^{2}$} & \multirow{3}{*}{$\mathbf{p}$} \\
\hline & \multicolumn{2}{|c|}{ Baik } & \multicolumn{2}{|c|}{ Kurang } & & \\
\hline & $\mathbf{n}$ & $\%$ & $\mathbf{n}$ & $\%$ & & \\
\hline \multicolumn{7}{|c|}{ Indeks BB/U } \\
\hline \multicolumn{7}{|l|}{ Energi } \\
\hline Cukup & 26 & 89,7 & 3 & 10,3 & 2,108 & 0,026 \\
\hline Kurang & 14 & 73,7 & 5 & 26,3 & & \\
\hline \multicolumn{7}{|l|}{ Protein } \\
\hline Cukup & 32 & 86,5 & 5 & 13,5 & 1,156 & 0,036 \\
\hline Kurang & 8 & 72,7 & 3 & 27,3 & & \\
\hline \multicolumn{7}{|c|}{ Indeks TB/U } \\
\hline \multicolumn{7}{|l|}{ Energi } \\
\hline Cukup & 27 & 93,1 & 2 & 6,9 & 2,103 & 0,032 \\
\hline Kurang & 15 & 78,9 & 4 & 21,1 & & \\
\hline \multicolumn{7}{|l|}{ Protein } \\
\hline Cukup & 32 & 86,5 & 5 & 13,5 & 0,152 & 0,049 \\
\hline Kurang & 10 & 90,9 & 1 & 9,1 & & \\
\hline \multicolumn{7}{|c|}{ Indeks BB/TB } \\
\hline \multicolumn{7}{|l|}{ Energi } \\
\hline Cukup & 28 & 96,6 & 1 & 3,4 & 2,289 & 0,016 \\
\hline Kurang & 16 & 84,2 & 3 & 15,8 & & \\
\hline \multicolumn{7}{|l|}{ Protein } \\
\hline Cukup & 34 & 91,9 & 3 & 8,1 & 0,011 & 0,048 \\
\hline Kurang & 10 & 90,9 & 1 & 9,1 & & \\
\hline
\end{tabular}

\section{Hubungan antara asupan zat gizi (energi dan protein) dengan status gizi subjek penelitian}

Hubungan antara asupan zat gizi (energi dan protein) dengan status gizi subjek berdasarkan indeks BB/U, TB/U, dan BB/TB disajikan pada Tabel 6. Dari tabel tersebut dapat diketahui adanya hubungan yang bermakna antara asupan zat gizi (energi dan protein) dengan status gizi subjek, baik berdasarkan indeks BB/U, TB/U, maupun BB/TB $(p<0,05)$. Hal ini berarti bahwa subjek yang memiliki asupan energi dan protein cukup, kemungkinan besar memiliki status gizi baik/normal.

Hasil penelitian ini sejalan dengan pendapat Soekirman (11) yang menyatakan bahwa asupan gizi berpengaruh terhadap status gizi, artinya bahwa dengan asupan gizi yang baik akan tercipta status gizi yang baik. Menurut Almatsier (15), status gizi adalah keadaan tubuh sebagai akibat konsumsi makanan dan penggunaan dari zat-zat gizi yang diperoleh oleh tubuh. Status gizi disebut optimal apabila tubuh memperoleh kecukupan zat-zat gizi yang dapat digunakan secara efisien, sedangkan status gizi kurang terjadi bila tubuh mengalami kekurangan satu atau lebih zat-zat gizi yang esensial.

Pada penelitian tentang faktor-faktor yang berhubungan dengan status gizi anak balita di Kecamatan Kertak Hanyar Kabupaten Banjar Provinsi Kalimantan Selatan juga menunjukkan adanya hubungan antara asupan makan dengan status gizi balita (16). Hubungan ini juga ditemukan dalam penelitian Amin (17) yang meneliti hubungan antara pola asuh dan asupan zat gizi dengan status gizi anak usia 6-24 bulan pada daerah pesisir pantai di Kelurahan Mangempang Kecamatan Barru Kabupaten Barru. Hasil penelitian tentang hubungan konsumsi energi dan status gizi anak umur 6-18 bulan di panti sosial anak se-DKI Jakarta dan Tangerang juga menemukan bahwa anak dengan asupan energi kurang mempunyai risiko 1,7 kali menjadi gizi kurang pada indeks TB/U dan 2,2 kali pada indeks BB/U (18). Selain itu, penelitian tentang faktor yang mempengaruhi perbaikan status gizi buruk membuktikan bahwa asupan energi berhubungan dengan membaiknya status gizi karena tingkat kecukupan energi yang berlebih akan disimpan tubuh dalam bentuk jaringan lemak di bawah kulit, sehingga dapat meningkatkan berat badan $(11,19,20)$.

Status gizi terutama ditentukan oleh ketersediaan zatzat gizi pada tingkat sel dalam jumlah yang cukup dan kombinasi yang tepat yang diperlukan tubuh untuk tumbuh, berkembang, dan berfungsi normal. Oleh karena itu, pada prinsipnya status gizi ditentukan oleh dua hal, yaitu: asupan zat-zat gizi yang berasal dari makanan yang diperlukan tubuh serta peran faktor yang menentukan besarnya kebutuhan, penyerapan, dan penggunaan zat-zat gizi tersebut (21).

\section{KESIMPULAN DAN SARAN}

Pola makan anak balita SAD dilihat dari jenis makanannya terbukti sebanyak $54,2 \%$ berada dalam kategori lengkap dan $45,8 \%$ tidak lengkap, sedangkan dilihat dari frekuensi makannya, sebanyak $52,1 \%$ berada dalam kategori baik dan 47,9\% tidak baik. Rata-rata asupan energi dan pro- 
tein anak balita SAD masing-masing adalah 1.020,93 $\pm 298,68$ $\mathrm{kkal} / \mathrm{hari}$ dan $28,49 \pm 8,08 \mathrm{~g} / \mathrm{hari}$. Anak balita SAD yang asupan energinya berada dalam kategori cukup dan kurang berturut-turut sebanyak $60,4 \%$ dan $39,6 \%$, sedangkan anak balita yang asupan proteinnya cukup dan kurang berturutturut sebanyak $77,1 \%$ dan $22,9 \%$. Status gizi anak balita SAD dengan menggunakan indeks $\mathrm{BB} / \mathrm{U}$ diperoleh sebanyak $16,7 \%$ anak balita mengalami gizi kurang, berdasarkan indeks TB/U sebanyak $12,5 \%$ anak balita berstatus gizi pendek, dan sebanyak $8,3 \%$ anak balita berstatus gizi kurus berdasarkan indeks BB/TB. Ada hubungan antara asupan zat gizi dengan status gizi anak balita SAD.

\section{RUJUKAN}

1. Azwar A. Kecenderungan Masalah Gizi dan Tantangan di Masa Mendatang, Makalah Pertemuan Advokasi Program Perbaikan Gizi Menuju Keluarga Sadar Gizi [serial online] 2004 Sept 27 [cited 2007 Jun 10]. Available from: http://www.gizi.net/makalah/makalah/dirjenSahid2.pdf.

2. Departemen Kesehatan RI. Laporan Penanggulangan Gizi Buruk di Indonesia Tahun 2005 [serial online] 2006 [cited 2007 Jul 18] (Internet). Available from: http:// w w w. g i z i. n e t / b u s u n g l a p a r / Lapgiziburuk2005.feb.2006.pdf.

3. Sediaoetama AD. IImu Gizi untuk Mahasiswa dan Profesi di Indonesia. Jakarta: Dian Rakyat; 2004.

4. World Bank. Repositioning Nutrition as Central to Devolopment A Strategy for Large-Scale Action. Washinton DC (USA): World Bank; 2006.

5. Dinkes Provinsi Jambi. Laporan Hasil Pemantauan Status Gizi. Jambi: Dinkes Provinsi Jambi; 2007.

6. Mulyadi. Karakteristik Masyarakat Suku Anak Dalam Ditinjau dari Aspek Kesehatan di Kabupaten Sarolangun Bangko. Jambi: Dinkes Provinsi Jambi; 2005.

7. Suhardjo, Kusharto CM. Prinsip-Prinsip IImu Gizi. Yogyakarta: Pusat Antar Universitas Pangan dan Gizi IPB dan Kanisius; 1992.

8. Dirjosoenyoto DR. Kajian Penelitian Gizi. Jakarta: Radar Jaya Offset; 1989.

9. Bunaya V, Muslim C, Karyadi B, Susanti L. Pola Konsumsi Pangan dan Status Gizi Balita di Desa Tertinggal Bengkulu Selatan. Medika 2005; XXXI(2): 80-3.

10. Menteri Kesehatan RI. Lampiran Keputusan Menkes RI tentang Klasifikasi Status Gizi Anak Balita. Jakarta: Departemen Kesehatan RI; 2002.

11. Soekirman. IImu Gizi dan Aplikasinya untuk Keluarga dan Masyarakat. Jakarta: Dirjen Dikti Depdiknas; 2000.
Hasil penelitian ini merekomendasikan agar pola makan, asupan zat gizi, dan status gizi anak balita SAD yang sudah baik tetap dipertahankan, sedangkan yang masih kurang diupayakan agar menjadi baik. Posyandu perlu dihidupkan untuk pemantauan pertumbuhan anak balita SAD secara rutin dan sebagai wadah dalam memberikan penyuluhan gizi, kesehatan dan pemberian makanan tambahan (PMT) kepada anak balita SAD. Kunjungan petugas puskesmas sebaiknya lebih ditingkatkan untuk memberikan pelayanan kesehatan, penyuluhan gizi, dan hal-hal lain dalam rangka meningkatkan status kesehatan dan gizi pada masyarakat SAD terutama anak balita.

12. Gibson RS. Antropometric Assesment Principles of Nutritional Assesment. New York: Oxford University Press; 2005. pp.41-60.

13. Aritonang I, Priharsiwi E. Status Bekerja Ibu Kaitannya dengan Pola Asuh Makan, Tingkat Kecukupan Energi Protein dan Status Gizi Anak Usia 0-59 Bulan di Perumahan Nogotirto Yogyakarta. Prosiding Temu IImiah pada Kongres XIII Persagi dan Festival Gizi; 20-24 November 2005; Bali, Indonesia.

14. Sudita T. Status Gizi dan Pola Makan Balita Suku Baduy di Kecamatan Leuwidamar Kabupaten Lebak Banten [tesis]. Yogyakarta: UGM; 2004.

15. Almatsier S. Prinsip Dasar Ilmu Gizi. Jakarta: Gramedia Pustaka Utama; 2001.

16. Ikhwansyah. Faktor-Faktor yang Berhubungan dengan Status Gizi Anak Balita di Kecamatan Kertak Hanyar Kabupaten Banjar Provinsi Kalimantan Selatan [tesis]. Yogyakarta: UGM; 2004.

17. Amin AM. Hubungan Pola Asuh dan Asupan Gizi terhadap Status Gizi Anak Usia 6-24 Bulan pada Daerah Pesisir Pantai di Kelurahan Mangempang Kecamatan Barru Kabupaten Barru [tesis]. Yogyakarta: UGM; 2003.

18. Rahmat M. Hubungan Konsumsi dan Status Gizi Anak Umur 6-18 Bulan di Panti Sosial Asuhan Anak se-DKI Jakarta dan Tangerang Tahun 1999. Info Pangan dan Gizi 2000;XI(1):15.

19. Werdiningsih A, Hadi H, Padmawati RS. Faktor-Faktor yang Mempengaruhi Perbaikan Status Gizi Balita Gizi Buruk di Kabupaten Bantul dan Sleman Jogjakarta. Berita Kedokteran Masyarakat 2001; XVII(4): 181-7.

20. Harper, Murray RK, Granner DK, Mayes PA, Rodwell WW. Biokimia. Jakarta: Penerbit Buku Kedokteran; 2001.

21. Waspadji S Pengkajian Status Gizi Epidemiologi. Jakarta: FK UI; 2003 